\title{
Pengembangan mie sagu ikan aneka warna dan rasa di Desa Banglas Barat Kecamatan Tebing Tinggi Kabupaten Kepulauan Meranti
}

\author{
Dewita*, Syahrul, Hendrik, dan Suardi Loekman \\ Fakultas Perikanan dan Kelautan, Universitas Riau \\ *dewi_58@yahoo.co.id
}

\begin{abstract}
Abstrak. Kabupaten Kepulauan Meranti merupakan salah satu sentra produksi sagu dan ikan di Provinsi Riau bahkan ditingkat nasional. Mie sagu merupakan produk makanan unggulan daerah tersebut dengan komposisi proksimat kaya karbohidrat dan miskin protein. Tujuan kegiatan PKM ini adalah (1) untuk alih teknologi pengolahan mie sagu ikan aneka warna dan rasa, (2) memperkenalkan teknologi pengolahan mie sagu yang difortifikasi konsentrat ikan dan udang, dan (3) meningkatkan nilai gizi mie sagu ikan aneka warna dan rasa sebagai produk unggulan daerah. Metode yang digunakan adalah metode sistem pembelajaran partisipasi aktif dengan tahap: (1) Tahap persiapan, yakni melakukan pendekatan kepada mitra dan penjelasan tujuan melaksanakan kegiatan PKM. (2) Tahap pelaksanaan, yaitu memberikan penyuluhan dan pelatihan kepada Mitra. Alih teknologi yang diberikan adalah pengolahan mie sagu ikan aneka warna dan rasa, selanjutnya dilakukan pendampingan selama satu bulan yang diakhiri tahap evaluasi kegiatan. Hasil yang diperoleh adalah kegiatan telah berlangsung dengan baik, dan mitra telah mendapat pengalaman langsung dalam alih teknologi produksi pengolahan mie sagu ikan aneka warna dan rasa. Kegiatan ini telah mampu memberikan pencerahan dan wawasan kepada mitra tentang pengembangan produk dan usaha. Kegiatan transfer teknologi menghasilkan respon peserta penyuluhan dan pelatihan khalayak sasaran dengan kategori 90\%sangat membantu dan $10 \%$ dapat membantu.
\end{abstract}

Kata kunci: konsentrat protein ikan; konsentrat protein udang; mie sagu

\begin{abstract}
Kepulauan Meranti regency is one of the centers of sago production and fish in Riau Province even at the national level. Sago noodles are the region's leading food products with a proximate composition high carbohydrates and low protein. The objectives of this PKM activity are (1) to transfer the technology of processing various-colored fish and sago noodles, (2) introducing the technology of processing sago noodles fortified with fish and shrimp concentrates, and (3) increasing the nutritional value of various colors and flavors of fish sago noodles as regional superior products. The method used is the method of active participation learning system with phases: (1) The preparation phase, which is to approach the partners and explain the purpose of implementing PKM activities. (2) The implementation phase, which is providing counseling and training to Partners. The technology transfer given is the processing of various colors and flavors of fish sago noodles, then one month of assistance is carried out which ends the evaluation phase of the activity. The results obtained are activities have taken place well, and partners have had direct experience in the transfer of technology in the production of various colors and flavors of fish sago noodles. This activity has been able to provide enlightenment and insight to partners about product and business development. Technology transfer activities resulted in participants' responses to counseling and training of the target audience that $90 \%$ was very helpful and $10 \%$ could help.
\end{abstract}

Keywords: fish protein concentration; sago noodles; shrimp protein concentration

To cite this article: Dewita, Syahrul, Hendrik, \& S. Loekman. 2019. Pengembangan mie sagu ikan aneka warna dan rasa di Desa Banglas Barat Kecamatan Tebing Tinggi Kabupaten Kepulauan Meranti. Unri Conference Series: Community Engagement 1: 186-191. https://doi.org/10.31258/unricsce.1.186-191

(C) 2019 Authors

Peer-review under responsibility of the organizing committee of Seminar Nasional Pemberdayaan Masyarakat 2019 


\section{PENDAHULUAN}

Kabupaten Kepulauan Meranti terpilih sebagai sentra produksi ikan dan sagu di Provinsi Riau dalam upaya pengembangan sistem agroindustri yang handal, sehingga daerah ini dijadikan sebagai wilayah Pengembangan kluster sagu dan ikan, mengingat produksi sagu sebesar 440.309 ton/tahun dan menghasilkan tepung sagu sebesar 9,89 ton/Ha (Anonim, 2010). Produksi hasil perikanan daerah ini sekitar 2.206,8 ton/tahun, sehingga diharapkan kedua komoditas ini dapat dikembangkan sebagai komoditas unggulan daerah.

Mie sagu merupakan salah satu produk makanan unggulan daerah kabupaten Kepulauan Meranti yang memiliki kandungan protein rendah yaitu sekitar 0,7\% dan tinggi kandungan karbohidrat (Siagian et al., 2013). Kadar protein tersebut perlu ditingkatkan dengan penambahan suatu bahan yang berkadar protein tinggi seperti konsentrat protein ikan. Konsentrat ikan adalah suatu produk berupa tepung untuk dikonsumsi manusia yang dibuat dari daging ikan utuh, dengan cara menghilangkan sebagian besar lemak dan kadar airnya, sehinga diperoleh persentase kandungan protein yang lebih tinggi.

Hasil penelitian Hibah Kompetensi oleh Dewita dan Syahrul (2010) menyatakan bahwa bahwa KPI patin memiliki kadar protein $75,31 \%$, dan mempunyai daya awet selama 45 hari dengan kemasan kertas aluminium. Hasil penelitian Dewita et al. (2014) menyatakan bahwa mie sagu yang difortifikasi dengan KPI patin dan diberi pewarna alami aneka warna dan rasa disukai oleh konsumen. Kegiatan pengabdian kepada masyarakat ini bertujuan untuk mengangkat potensi sagu dan perikanan yang ada di daerah Riau khususnya kabupaten Kepulauan Meranti untuk dijadikan sebagai sumber pendapatan alternatif guna memperbaiki tingkat kesejahteraan masyarakat dan menjadi produk unggulan daerah tersebut.

Hasil penelitian Dewita et al. (2013) menyatakan bahwa nilai protein dan karbohidrat dari mie sagu instan yang difortifikasi dengan KPI patin sebanyak $10 \%$ adalah protein $5,57 \%$ dan karbohidrat $82,16 \%$ serta mempunyai daya simpan selama 90 hari dengan mengunakan kertas aluminium foil. Hasil penelitian selanjutnya pada mie sagu yang difortifikasi dengan KPI patin mengandung hampir semua jenis asam amino esensial (Dewita et al., 2014). Alih teknologi kepada pelaku UMKM mie sagu di desa Bangsal Barat Kecamatan Tebing Tinggi Kabupaten Kepulauan Meranti perlu dilakukan melalui Pelatihan pengolahan mie sagu ikan aneka warna dan rasa.

Kegiatan Program Kemitraan Masyarakat (PKM) ini bertujuan untuk: (1) alih teknologi pengolahan mie sagu ikan aneka warna dan rasa pada kelompok usaha mie sagu diKabupaten Kepulauan Meranti, khusus kelompok mitra kegiatan, (2) memberikan pencerahan dan wawasan pengembangan produk dan usaha mie sagu, dan (3) meningkatkan produksi dan pendapatan pelaku usaha mie sagu.

\section{MASALAH}

Kelompok usaha mie sagu terutama kelompok mitra pada umumnya belum ada perubahan, yakni mengolah mie sagu tanpa penambahan sumber protein untuk meningkatkan nilai gizi, sedangkan mie sagu yang ada saat ini merupakan makanan khas dan kegemaran dari masyarakat Kabupaten Kepulauan Meranti ini serta memiliki kandungan nutrisi yang rendah protein dan hanya kaya akan karbohidrat. Alih teknologi pembuatan mie sagu ikan aneka warna dan rasa perlu dilakukan pada usaha kelompok usaha mie sagu yang menjadi mitra dari kegiatan PKM ini di desa Banglas Barat Kabupaten Kepulauan Meranti.

\section{METODE}

\section{Masyarakat dan Kelompok Sasaran}

Masyarakat dan kelompok sasaran merupakan pengusaha mikro dalam bidang pengolahan mie sagu, yang berada di desa Banglas Barat kecamatan Tebing Tinggi Kabupaten Kepulauan Meranti. Kedua Mitra Usaha mie sagu tersebut, adalah UD Timur Jaya dan UD tiga Putra, keduanya memiliki karakteristik yang menarik dan dapat membangun hubungan mutualisme yang saling menguntungkan. Hubungan mutualisme itu dapat dijelaskan UD Timur Jaya adalah UMKM yang sudah lama berdiri sehingga telah memiliki pangsa pasar yang luas; sedangkan UD Tiga Putra merupakan UMKM yang baru berdiri, dengan demikian UMKM UD Timur Jaya dapat memberikan pengalaman terutama pangsa pasarnya kepada UMKM UD Tiga Putra untuk dapat berkembang.

\section{Metode Pelaksanaan Kegiatan}

Alih Teknologi yang diterapkan kepada mitra adalah: (1) teknologi pengolahan mie sagu ikan aneka warna dan rasa, (2) teknologi berproduksi dengan baik (good manufacturing practice, GMP) dan (3) Manajemen pengembangan produk dan usaha berbasis sagu terutama manajemen pemasaran. Alih teknologi tersebut 
dilakukan dengan menggunakan metode PALS, prinsip dasar dari metode PALS (Participatory Action Learning System, adalah pelibatan anggota kelompok, termasuk pengurus kelompok dan mietra IbM dalam proses pembelajaran aktif partisipan dalam program aksi penerapan kepada mitra, sehingga dapat meningkatkan keterampilan dan teknologi UMKM yaitu dengan cara pengenalan teknologi proses pengolahan mie sagu ikan aneka warna dan rasa, pengenalan tentang sanitasi di tempat usaha, dan memberikan penguatan dari aspek manajemen dan tata kelola usaha. Kegiatan yang dilakukan untuk mencapai sasaran dimaksud adalah dengan tahapan sebagai berikut:

\section{Tahap Persiapan}

Tahap persiapan merupakan tahap yang diperlukan untuk mengumpulkan informasi terakhir berkaitan dengan dasar-dasar pelaksanaan pelatihan dan mempersiapkan segala sesuatu yang diperlukan dalam pelaksanaan kegiatan.

Tahap persiapan ini terdiri dari:

1. Diskusi dengan anggota pelaksana kegiatan dan penentuan pembagian beban kerja diantara anggota tim.

2. Menghubungi instansi-instansi lain yang terkait dalam pelaksanaan kegiatan

3. Mempersiapkan peralatan serta bahan yang diperlukan dalam pelaksanaan Pelatihan.

\section{Tahap Pelaksanaan Kegiatan}

Tahap ini merupakan tahap yang diperlukan untuk melaksanakan Pelatihan. Tahap ini terdiri dari:

1. Tahap pertama (bulan kedua)

Tahap ini diberikan pembekalan dasar-dasar teoritis yang berkaitan dengan alih teknologi yang meliputi: penanganan ikan segar, penggunaan bahan-bahan tambahan pangan, pengetahuan mengenai sanitasi, dan jenis dan caara pengemasan produk

2. Tahap kedua (bulan ketiga)

Tahap kedua merupakan tahapan melakukan praktek/pelatihan teknologi pembuatan mie sagu ikan aneka warna dan rasa dengan teknologi sederhana sesuai dengan teoritis yang telah diberikan sebelumnya.

3. Tahap ketiga (bulan keempat)

Tahap ketiga dilakukan pembentukan kelompok usaha terpadu dengan metode kluster, yakni membuat suatu jaringan bisnis antara pembudidaya ikan patin, pengolah mie sagu dan kelompok pemasaran.

4. Tahap keempat (bulan kelima dan keenam)

Tahap ini menyarankan kelompok usaha untuk mengurus lisensi produk mie sagu ikan aneka warna dan rasa yang mengandung protein tinggi pada instansi terkait seperti Dinas Kesehatan setempat untuk mendapatkan Izin Rumah Tangga (IRT).

5. Tahap kelima (bulan ketujuh dan kedelapan)

Tahap ini merupakan tahap monitoring dan pembinaan terhadap kelompok usaha agar konsisten dalam mengembangkan usahanya. Data hasil monitoring dan evaluasi dibahas bersama kelompok usaha, dan selanjutnya data hasil pembahasan tersebut diolah dan disusun menjadi suatu laporan. Laporan ini akan diserahkan ke DRPM Kemenristek Dikti RI.

\section{Metode Penyuluhan dan Pelatihan}

Metode yang digunakan untuk mencapai tujuan sebagaimana yang telah ditetapkan adalah metode diskusi dan praktek (learning by doing). Gabungan kedua metode tersebut diharapkan mampu meningkatkan pemahaman dan keterampilan khalayak berkaitan dengan teknologi pengolahan mie sagu ikan aneka warna dan rasa.

\section{Rancangan Evaluasi Dan Kriteria Keberhasilan}

Kegiatan evaluasi program pengabdian ini dilakukan melalui pengamatan langsung dengan penilaian kinerja dalam proses persiapan, pelaksanaan dan evaluasi. Tingkat keberhasilan pelatihan ditentukan melalui evaluasi yang dilakukan Tim Pelaksana dengan menggunakan indikator yang tercantum dalam Tabel 1 . Sementara hasil akhir penilaian kinerja dirata-ratakan dan dikonversi menggunakan pedoman konversi dapat dilihat pada Tabel 2 . 
Tabel 1. Check list proses

\begin{tabular}{|c|c|c|c|c|c|}
\hline \multirow{2}{*}{ No } & \multirow{2}{*}{ Keterampilan yang Diamati (Indikator) } & \multicolumn{4}{|c|}{ Skala Nilai } \\
\hline & & 4 & 3 & 2 & 1 \\
\hline 1 & Persiapan (Pemilihan bahan ,penimbangan, penyiapan alat) & & & & \\
\hline 2 & Penggunaan peralatan yang benar & & & & \\
\hline 3 & Ketepatan langkah-langkah mengolah produk & & & & \\
\hline 4 & $\begin{array}{l}\text { Kesesuaian hasil akhir yang dipresentasikan menurut kreteria yang diharapkan dalam } \\
\text { resep }\end{array}$ & & & & \\
\hline 5 & Menata peralatan setelah mengolah & & & & \\
\hline 6 & Teknik pengemasan & & & & \\
\hline 7 & Analisis untuk menghitung rugi /laba produk & & & & \\
\hline
\end{tabular}

Keterangan: $4=$ sangat baik, $3=$ baik, 2= cukup, $1=$ kurang

Sumber: Santyasa (2006)

Tabel 2. Pedoman konversi nilai

\begin{tabular}{cccc}
\hline No & Rentangan & Skor Nilai & Kategori \\
\hline 1 & $85 \%-100 \%$ & 4 & Sangat baik \\
2 & $70-84 \%$ & 3 & Baik \\
3 & $55-69 \%$ & 2 & Cukup \\
4 & $\leq 54 \%$ & 1 & Kurang \\
\hline
\end{tabular}

\section{PEMBAHASAN}

\section{Kegiatan yang Telah Dilaksanakan}

Kabupaten Kepulauan Meranti merupakan penghasil sagu dan ikan yang terbesar di provinsi Riau. Areal tanaman sagu yang ada 37.961 hektar dengan produksi sagunya 440.309 ton/tahun, selain itu meskipun sektor perkebunan dan pertanian mendominasi aktivitas perekonomian masyarakat, namun kontribusi sektor perikanan di daerah ini menjadi lebih dominan mengingat rata-rata produksi dan pemasaran ikan adalah 2.206,8 ton/tahun, sehingga diharapkan kedua komoditas (sagu dan ikan) tersebut dapat dikembangkan sebagai komoditas unggulan daerah setempat. Selat Panjang merupakan ibukota kabupaten Kepulauan Meranti, yang salah satu desanya adalah desa Banglas Barat kecamatan Tebing Tinggi Kabupaten Kepulauan Meranti yang mengolah sagu menjadi mie sagu, sehingga daerah ini dikenal sebagai penghasil mie sagu Selat Panjang. Berdasarkan potensi tersebut, inovasi teknologi fortifikasi dan diversifikasi produk olahan berbasis sagu dan ikan menjadi sangat menjanjikan untuk dikembangkan, salah satunya adalah mie sagu ikan aneka warna dan rasa yang kaya asam amino essensial (Dewita et al., 2014)

Pengolahan mie sagu yang dilakukan oleh masyarakat setempat secara teknis masih digolongkan ke dalam teknologi sederhana, mengingat mie sagu yang ada saat ini kaya karbohidrat tetapi miskin protein maka perlu adanya terobosan untuk meningkatkan nilai gizi mie sagu dengan penambahan bahan dari sumber protein ikan. Teknologi pengolahan seperti ini tentu saja menghasilkan produk dengan variasi kualitas yang berbeda, mengingat pada waktu tertentu permintaan mie sagu basah mengalami penurunan, selain itu untuk menghindari terjadinya persaingan antar sesama mie sagu dan dinamika pertumbuhan, timbul keinginan dari masyarakat untuk menganekaragamkan produk mie sagu dengan penambahan konsentrat Protein ikan. Berbagai hasil penelitian yang telah dilakukan oleh jurusan Teknologi Hasil Perikanan Fakultas Perikanan dan Ilmu Kelautan Universitas Riau, antara lain produk cake brownies yang difortifikasi dengan KPI (Wirda, Dewita, dan Loekman, 2014), Nugget bonggol pisang yang difortifikasi dengan KPI ikan (Syaputra, Dewita, dan Suparmi, 2013) dan bubur instan berbahan baku KPI ikan (Dewita dan Syahrul, 2012).

Produk hasil penelitian tersebut ternyata sangat diminati oleh konsumen, hal ini menjadi pendorong bagi perguruan tinggi untuk mentransfernya kepada kelompok usaha kecil pengolahan mie sagu untuk membuka 
usaha/industri kecil yang bergerak dibidang miee sagu ikan. Salah satu industri pengolahan mie sagu yang menjadi sasaran sebagai mitra adalah kelompok usaha kecil pengolahan mie sagu UD. Timur Jaya dan UD Tiga Putera di desa Banglas Barat Kecamatan Tebing Tinggi Kabupaten Kepulauan Meranti. Inovasi teknologi yang diberikan adalah: (1) metode pembuatan mie sagu ikan aneka warna dan rasa; (2) penggunaan alat pengolahan ,pencetak dan kemasan produk; dan, (3) kiat-kiat dalam pengembangan usaha.

Kegiatan PKM yang dilakukan adalah diskusi antara tim PKM dengan mitra, yang bertujuan untuk merealisasikan kegiatan PKM ini. Kegiatan ini juga dilakukan kepada mitra dengan memberikan workshop dan gambaran tentang prospek pengolahan mie sagu yang dapat dilakukan, oleh karena itu untuk pengembangan produk dapat dilakukan dengan fortifikasi tepung ikan teri dan udang pada mie sagu. Hal ini sesuai dengan perkembangan teknologi, saat ini pengembangan produk sangat memungkinkan untuk mendapatkan keuntungan bagi industri makanan.

Kabupaten Kepulauan Meranti merupakan daerah penghasil sagu terbesar di provinsi Riau bahkan ditingkat nasional. Potensi sagu ini perlu dimanfaatkan terutama untuk pengolahan mie sagu. Mie sagu yang diolah oleh UMKM umumnya mieskin kandungan protein, sehingga perlu terobosan melalui fortifikasi konsentrat ikan. Hasil penelitian kami terdahulu bahwa kandungan protein mie sagu yang difortifikasi konsentrat ikan teri dan udang dapat meningkatkan kandungan protein menjadi 5,75\%. Berarti fortifikasi konsentrat ikan patin sebesar 10\% dapat menambah nilai gizi mie sagu, maka dari itu kegiatan PKM ini dilaksanakan.

\section{Respon Masyarakat Sasaran}

Kebiasaan masyarakat umumnya masih sulit atau resisten terhadap sesuatu program yang baru bagi mereka, akan tetapi apabila program tersebut menyentuh kebutuhan mereka maka mereka akan menerima program pembaharuan. Mengingat program kegiatan alih teknologi yang diberikan sangat menarik dan menurut mereka sangat dibutuhkan, maka respon masyarakat terhadap kegiatan ini sangat antusias, dari data yang diperoleh berdasarkan observasi dan wawancara bahwa respon peserta menyatakan sangat bermanfaat sekitar 90\% dan bermanfaat sekitar 10\%. Hal ini menunjukan bahwa masyarakat sasaran sangat antusias terhadap kegiatan alih teknologi ini, sehingga perlu direalisasikan.

\section{KESIMPULAN}

Berdasarkan hasil kegiatan pengabdian kepada masyarakat dalam bentuk PKM yang telah dilaksanakan, dapat disimpulkan sebagai berikut:

1. Penyuluhan dan pelatihan fortifikasi konsentrat ikan dan udang dalam pengolahan mie sagu pada UMKM mitra di kabupaten Kepulauan Meranti khusus UD. Timur Jaya dan UD. Tiga Putra Selat Panjang telah menambah ragam produk mie sagu sehingga membuka peluang peningkatan produksi dan pemasaran bagi pelaku industri dan masyarakat setempat.

2. Pemanfaatan sagu menjadi mie sagu ikan aneka warna dan rasa secara ekonomi mampu berkontribusi untuk peningkatan produksi dan pemasaran mie sagu.

3. Kualitas mie sagu yang dihasilkan setelah difortifikasi konsentrat ikan dan udang dapat meningkatkan kandungan protein dari $0,7 \%$ menjadi $7,55 \%$ untuk mie ikan dan $8,45 \%$ untuk mie udang.

4. Respon masyarakat sasaran setelah kegiatan alih teknologi adalah $90 \%$ sangat membantu, dan $10 \%$ membantu.

\section{DAFTAR PUSTAKA}

Anonim. 2010. Kabupaten Kepulauan Meranti dalam Angka. Sekretariat Kabupaten Kepulauan Meranti Provinsi Riau.

Dewita, dan Syahrul. 2010. Kajian Konsentrat Protein Ikan Patin dan Masa Simpannya dalam Kemasan Berbeda. Laporan Penelitian Hibah Kompetensi Tahun 2010. Lembaga Penelitian Universitas Riau.(tidak dipublikasikan).

Dewita, dan Syahrul. 2012. Kajian Diversifikasi Ikan Patin dalam Bentuk Konsentrat Protein Ikan dan Aplikasinya pada Produk Makanan Jajanan untuk Menanggulangi Gizi Buruk pada Anak Balita di Kabupaten Kampar. Prosiding Seminar Antar bangsa Ke-4 Ekologi, Habitat Manusia dan Perubahan Lingkungan di Malaysia.Poseding Seminar Internasional UKM malaysia.

Dewita, Syahrul, dan Desmelati. 2013. Optimalisasi Formula Aneka Mie Sagu Instan yang Difortikasi Konsentrat Ikan Patin Siam (Pangasius hypophthalmus) Sebagai Makanan Potensial Bergizi Tinggi. Jurnal Penelitian BERNAS $8(2)$. 
Dewita, Syahrul, dan Desmelati. 2014. Forifikasi Konsentrat Protein Ikan Patin Kaya Asam Amino Esensial pada Pengolahan Mie Sagu Instan Sebagai Produk Unggulan Daerah Kabupaten Kepulauan Meranti Riau. Jurnal Penelitian BERNAS 9(2).

Santyasa, I. W. 2006. Pembelajaran Inovatif: Model Kolaboratif, Basis Proyek, dan Orientasi NOS. Semarapura: Makalah.

Siagian, U.W., V. S. Johan, dan S. Pato. 2013. Pemanfaatan Tepung Kulit Singkong dalam Pembuatan Mie Sagu Instan. Sagu 12(2): 32-39.

Syaputra, D., Dewita, dan Suparmi. 2013. Fortifikasi Konsentrat Protein Ikan Patin (Pangasius Hypophthalmus) pada Nugget Bonggol Pisang terhadap Penerimaan Konsumen. JOM FAPERIKA UNRI: 1-8.

Wirda, H., Dewita, dan S. Loekman. 2014. Fortifikasi Konsentrat Protein Ikan Patin (Pangasius Hypophthalmus) dalam Pembuatan Cake Brownies. JOM FAPERIKA UNRI: 1-8. 